\title{
Evolution at the University of Maryland Libraries
}

Not revolution, but normal development, is the key to the changes described by the librarian of the University of Maryland.

$\mathrm{T}$ HE ADMINistration of collegiate libraries in a university and their relationship to the general library and the university librarian, or director of libraries, is a subject which has engaged the attention of many librarians, professors, deans, and even university presidents. In the main there have been two schools of thoughtthe faculty, in many cases, seeking to maintain independent collegiate libraries while librarians have striven for centralized library systems, administratively speaking. As a result, various surveys of the subject made over a period of years show a wide variety of practice, ranging from a high degree of centralization to complete independence for certain of the professional school libraries. ${ }^{1}$ It is interesting to note in this connection that the recently published Handbook of Medical Library Practice has selected as a typical administrative organization in a university one in which the university librarian is described as the "nominal head of the dental library," with the direct flow of authority passing not through his hands but vested in the dean. ${ }^{2}$ In general, however, recent administrative

1 A.L.A. Survey of Libraries in the United States. Chicago, A.L.A., 1926. v. 1, p. 168-95. Hausdorfer, Walter. Professional School and Departmental Libraries. New York City, Special Libraries Associa-
tion, r 939 . Works, George Alan. College and Unition, 1939 . Works, George Alan. College and Uni-
versity Problems. Chicago, A.L.A., 1927, p. 63-79. versity Problems. Chicago, A.L.A., 1927, p. 63-79.
2 Doe, Janet, ed. A Handbook of Medical Library Practice. Chicago, A.L.A., 1943, p. 12. trends appear to be in the direction of centralization of control in library systems, as well as in other types of enterprises. In fact, if the generally accepted principles of administrative organization as discussed, for instance, by Reeves in Current Issues in Library Administration, ${ }^{3}$ are followed, a centralized library system must almost inevitably result. It is the purpose of this paper to describe the development of an administrative relationship based on the thesis of centralized control which, on the basis of experience, has proved its worth and practicability.

\section{The Setting}

The University of Maryland is a stateowned and state-controlled university, formed by a merger in 1920 of the old privately-owned and operated University of Maryland in Baltimore and the Maryland State College at College Park. The Baltimore division traces its history back to $\mathrm{I} 807$ when the College of Medicine of Maryland was organized. In 1812 the General Assembly of Maryland authorized the College of Medicine of Maryland to "annex or constitute faculties of divinity, law, and arts, and sciences," and by the same act declared that "the colleges or faculties thus united should be constituted an university by the name and under the title of the University of Maryland." By authority

${ }^{3}$ Reeves, Floyd W. "Some General Principles of ${ }^{3}$ Reeves, Floyd W. "Some General Principles of
Administrative Organization." (In Joeckel, Carleton
B., ed. Current Issues in Library Administration. Chicago, University of Chicago Press, 1939, p. I-21.) 
of this act, steps were taken in 1813 to establish "a faculty of law," and in 1823 a regular course of instruction in law was undertaken. Subsequently there were added: in 1882 , a department of dentistry, which was united in 1923 with the Baltimore College of Dental Surgery, founded in 1840 ; in 1889 , a school of nursing; and in 1904, the Maryland College of Pharmacy, founded in $184 \mathrm{I}$. The Maryland State College, at College Park, was chartered in 1856 as the Maryland Agricultural College and did not receive the current designation until 1916. Prior to 1920 then, the two units were separate and distinct one from another. These divergent origins of the present university, which have been only briefly summarized here, together with the physical separation of facilities, must be realized and accepted as a complicating factor in the administrative process. However, the University of Maryland is not alone in this respect, at least as far as the geographical factor is concerned, as several of our outstanding institutions are in a similar situation. ${ }^{4}$

\section{The Situation in 1937}

In 1937 the libraries of the university consisted of the general library at College Park (65,000 volumes), the dental library $(5,700$ volumes $)$, the law library ( 14,200 volumes), the medical library (18,000 volumes), and the pharmacy library $(6,500$ volumes) in Baltimore. Each of these libraries operated as an independent entity, with the librarian at College Park responsible to the president of the university and the staff members of the four libraries in Baltimore responsible to the respective

\footnotetext{
4 University of Colorado, Boulder-School of medicine in Denver.

University of Illinois, Urbana-Schools of dentistry, medicine, and pharmacy in Chicago.

Indiana University- Bloomington-Schools of dentistry, medicine, and nursing in Indianapolis.

Northwestern University, Evanston, Ill.- Schools of law, dentistry, and medicine in Chicago.

Unniversity of Tennessee, Knoxville-Schools of dentistry, medicine, nursing, and pharmacy in Memphis.
}

deans. It is true that a degree of informal cooperation had been achieved between the dental and pharmacy libraries, largely because they occupied common quarters in the dental-pharmacy building. The law library was housed in the law school building half a block away, and the medical library in a converted church building across the street. The staff in Baltimore totaled eight -two in the medical library, two in the pharmacy library, one in the law library, and three in the dental library-carried on the budgets of the respective schools. One of the three dental library staff members, a cataloger, was paid from the Grieves $\mathrm{Li}$ brary Foundation Fund and in this respect perhaps could not properly be classed as a university employee. This position, however, terminated in June 1938 .

The first step toward a coordination of the university's library resources and policies came with the appointment of the present director of libraries as university librarian in September 1937, with specific responsibility for all libraries of the university. This was a decided innovation and required the exploration of unplotted territory in intra-university relationships.

\section{Procedure}

Inasmuch as the main seat of university administration was on the College Park campus, it was only natural that the library system should center there administratively. The general library presented no particularly unusual problems of an administrative nature, so the new office merely represented a change in executives as far as it was concerned. Apart from an occasional reference, the general library has no part in the material which follows.

The first task was to become thoroughly familiar with resources of personnel and materiel and with conditions, and to this end the university librarian spent on the average two days a week in the Baltimore 
libraries during the first year. Early in this period he became convinced that the most suitable plan would be to provide for centralized administration and preparations, with decentralized service. The physical location of the four libraries, combined with custom and the desirability of having materials readily available to classrooms, rendered a centralization of facilities undesirable, if not impossible.

For some time the university librarian's duties, as far as the Baltimore libraries were concerned, were almost purely of a consultative nature. Major issues and problems of service, personnel, and policies were discussed with the deans, but the day-byday work of the libraries was still remote. The opportunity to make a change came in the fall of 1940 , when the dean of the dental school proposed to reactivate the cataloging position vacant since June 1938. By this time one of the other dental library positions was vacant too. The university librarian urged that the funds available for these two positions be utilized to secure one individual to take charge of both dental and pharmacy libraries, that the pharmacy cataloger assume responsibility for dental library cataloging as well, and that the balance of the money available be used for a clerktypist to assist the cataloger. The deans of the dental and pharmacy schools approved this proposal. As a result, on Jan. I, I94I, a staff member was transferred from the general library at College Park to become librarian of the dental-pharmacy library. Here for the first time centralized control and preparations went into effect, inasmuch as there was now one individual responsible for general supervision, correspondence, and ordering; one individual, with a clerical assistant, for classification and cataloging; and two who were able to devote their entire energies to service to readers. The over-all number of staff members was not larger than in 1937-38, although the composition had changed somewhat. Salary costs, increased by five hundred dollars over the 1937-38 figure, were still carried on the budgets of the respective schools. Pharmacy, in return for relinquishing a portion of the services of its cataloger, received the benefits derived from the new librarian's appointment and the additional services of the typist. It should be pointed out, incidentally, that the combined annual accessions of both libraries, totaling in the neighborhood of 1500 volumes, can be processed by the cataloger and her clerical assistant without difficulty. As a result of the changes described above, the number of distinct units in Baltimore was. reduced from four to three.

\section{The Medical Library}

Following a series of conferences between the university librarian and the acting dean and library committee of the medical school, the medical library came into the scheme on Oct. I, 1942, with the librarian of the dental-pharmacy library assuming responsibility for its administration under the general direction of the university librarian. The medical school agreed to carry one third of the librarian's salary and one third of the typist's salary. To offset this reduction of assistance in the dental-pharmacy library an additional staff member was appointed to be paid in the main from funds released by the assumption of a portion of the two salaries by the medical school. At the same time hours of service were increased from $43 \frac{1}{2}$ to $53 \frac{1}{2}$ a week in the dental-pharmacy library, thereby amply offsetting any slight increase in salary costs to these schools. A further step forward was taken at this time, as the schools agreed to transfer salary funds to the general library budget each year, so that all library staff members are now on a centralized budget.

With this change in administrative or- 
As existing in 1937

\begin{tabular}{|c|c|c|c|c|}
\hline \multicolumn{5}{|c|}{ President of the University } \\
\hline Librarian & Dean, Dental School & Dean, Law School & Dean, Medical School & Dean, Pharmacy School \\
\hline $\begin{array}{l}\text { General Library } \\
\text { College Park }\end{array}$ & $\begin{array}{l}\text { Dental Library } \\
\text { 3 Staff Members }\end{array}$ & $\begin{array}{l}\text { Law Library } \\
\text { I Staff Member }\end{array}$ & $\begin{array}{l}\text { Medical Library } \\
2 \text { Staff Members }\end{array}$ & $\begin{array}{l}\text { Pharmacy Library } \\
2 \text { Staff Members }\end{array}$ \\
\hline
\end{tabular}

January 1938

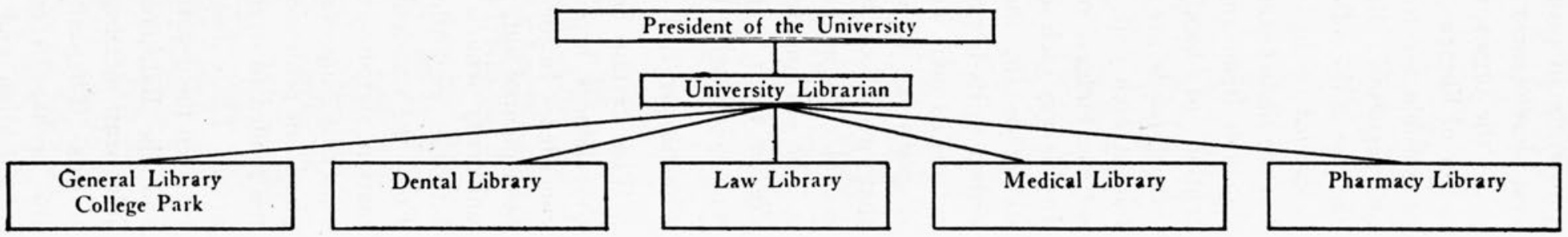

In 1943, after reorganization

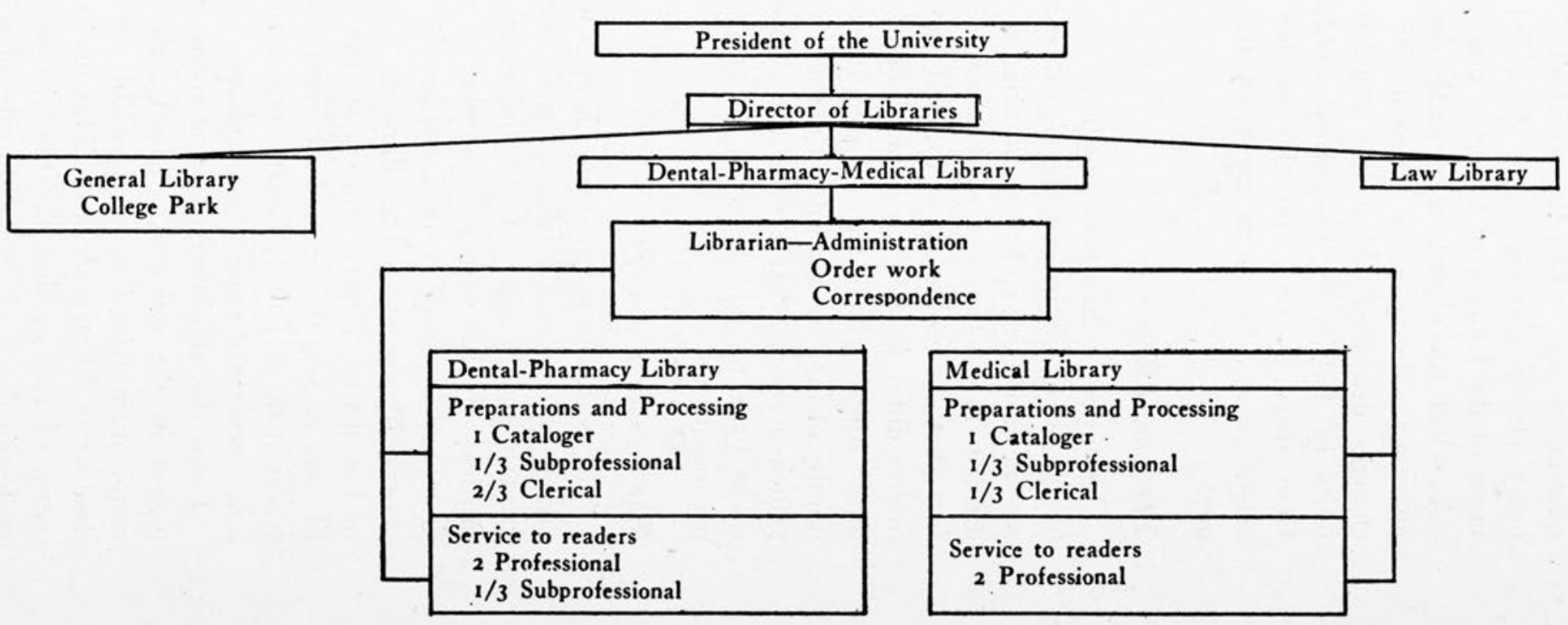


ganization, the medical school was persuaded to provide funds for a full-time cataloger and, as a result, recataloging and reclassification of the medical collection is now under way. The Boston Medical Library classification is being discarded in favor of the Library of Congress classification, which was already in use in the dentalpharmacy library. As a result of the changes described above, the number of units in Baltimore was further reduced from three to two and the number of classification schemes in use from two to one.

\section{The Law Library}

No attempt has been made as yet to bring the law library into the organizational scheme and to have the law librarian report directly to the university librarian. The fact that its problems, needs, and subject matter differ so radically from those of the other units, which have a definite community of interest and subject matter, is the principal reason. At present there appears to be little to gain from an arbitrary reorganization.

\section{The Situation in 1943}

The period in which these changes were taking place was also that of the greatest growth on the part of the university libraries. By June 1943 the number of volumes had increased to over IOI,000 in the general library at College Park, to ro,ooo in the dental library, 18,000 in the law library, 22,500 in the medical library, and 9,200 in the pharmacy library, representing a net increase of some 50,000 volumes.

From the administrative standpoint one person in the university, namely, the director of libraries, is now responsible for the conduct of library service. This does not mean, of course, that the libraries of the professional schools are administered without regard to the wishes of the respective deans and faculties, since consultations are constantly in progress looking toward the best development and greatest usefulness.

As the organization now stands the director of libraries, with his staff, is entirely responsible for technical processes, service, and personnel. Book selection, as is usually the case in the college and university library, is carried on in large part by the faculty, but the library staff is active in checking for desirable items and calling them to the attention of faculty members concerned. Salary funds are transferred to a central budget each year while book funds remain on the budgets of the individual schools. In this way each school is enabled to express its interest by the degree of support furnished to its library, which still, of course, retains its own identity as a collection. It is gratifying to report in this connection that two schools have increased book funds considerably in the past two or three years.

The old and new plans of organization are set forth graphically in the charts on an accompanying page.

\section{Conclusions}

That certain benefits have derived from the changes herein described is generally conceded. In the first place, as has already been pointed out, there is one person in the university who is cognizant of all library activities regardless of school or locale. From the standpoint of coordinating information, statistics, and reports, this has been especially important. The increased emphasis on professional training and conduct has tended to strengthen morale and standards. There has been closer cooperation between the general library at College Park and the Baltimore group culminating in joint staff meetings at not too frequent intervals. The staff has increased in size but this perhaps is only incidental to the reorganization and might have taken place

(Continued on page 22) 


\section{Limits of Collections}

Another suggested basis for limiting our collections is by division of subject responsibility with other libraries. In respect to manuscripts and very rare books this is probably inevitable. The professional material we have already abandoned to other libraries. Our requirements otherwise are so large that any proposal to limit the collections should be approached with the utmost caution. But neither should we agree to accept responsibility for making exhaustive collections in any subject, since this would compel us to get the professional books, manuals, reprints, and translations, of which we have made a general exception. Even in the event of cooperative agreements it would be unnecessary to acquire all these classes of publications because professional libraries in the city will get them anyway.

The library as we have attempted to describe it in our report is a metropolitan research institution. In my opinion, shared to greater or less degree by members of the committee, supplying visitors with information on the repair of automobiles or preparation of income tax returns is merely one of its incidental functions and one which could be performed better by libraries in which the catalogs and distances are smaller. Our resources should not be dissipated in purchasing material of temporary usefulness, still less in duplicating it.

The ultimate purpose of our collections is to preserve the true record of human life. In Amiel's Journal is an observation pertinent to our work here: "A lively, persistent and disinterested liking for the truth is extraordinarily rare." Yet it is this same liking for the truth, together with the intelligence to recognize it, which is the mark of the educated man. It is our job to provide an instrument for the use of educated men in the hope that eventually we shall have contributed to the development of an educated community.

\section{Evolution at the University of Maryland Libraries}

\section{(Continued from page 12)}

anyway. It is without doubt more flexible and consequently better adapted to handle emergencies caused by illness or resignations. There has been a standardization of procedures, service, and hours, as well as a greater utilization of resources through knowledge of the holdings of the other libraries. The purchase of duplicate expensive items can be controlled by means of centralized ordering.
A final point which appears to merit emphasis is the fact that this is an organization which has come about as the result of guided evolution and not revolution. It was developed in concert and on the basis of mutual agreement rather than by edict on the part of the university administration. Moreover, it contains within itself the seeds for further development without departing from the present basic lines. 